\title{
Chromosome Polymorphism and Nucleolar Organization in Some Species of Fritillaria Linn.
}

\author{
A. K. Koul and B. A. Wafai \\ Department of Biosciences, University of Jammu, \\ J \& K State, India
}

Received January 11, 1979

The genus Fritillaria Linn. comprised of about a hundred species is polybasic with $\mathrm{x}=9,11,12$ and $13 ; 12$ is, however, the focal number. The 64 species of which chromosome counts are known, are all diploid with only a few existing in polyploid state as well (See Fedorov 1969). Although a sizable number of species contain chromatin fragments and accessory chromosomes the numerical homogeneity is so remarkable that it excludes the hand of polyploidy in speciation within the genus. Mutations and/or structural alterations of chromosomes are perhaps the two major factors of evolutionary significance. Should this be true, detailed karyology may yield some data of genuine taxonomic relevance.

Cytologically, species of Fritillaria are interesting. Not only do they vary in the detail of H-band patterns (Dyer 1963) they also exhibit variation in the number, size and other details of nucleolar chromosomes both at inter- and intraspecific levels. Thus, while var. No. " 5 " of $F$. imperialis possesses a single pair of nucleolar chromosomes, var. "crown- upon- crown" has two such pairs (Darlington 1930). Observations made on the somatic chromosomes of $F$. roylei (Sharma and Sharma 1961, Chatterjee 1971, Mehra and Sacchdeva 1976) also indicate clonal variability in respect of nucleolar chromosomes.

But for the solitary work of Frankel (1937) no data are available on nucleolar organization in the genus although such a study is likely to make an interesting line of investigation in view of the nucleolar chromosome polymorphism referred to above.

\section{Materials and methods}

F. imperialis L. is extensively distributed in Jammu and Kashmir state growing wild along hill slopes in Baramulla, Zaberwan, Pirpunjal and Gulmarg areas (1,600$3,000 \mathrm{~m}$ ). It has also been brought under cultivation in gardens and parks of the valley. F. roylei Hook. on the contrary is restricted to much higher altitudes $(3,500$ $4,000 \mathrm{~m}$ ). For the present investigation it was collected from Khilanmarag (in Kashmir province) and Sioj (in Jammu province).

Somatic chromosomes were studied from actively dividing root tip cells obtained in wet sand. The root tips were pretreated with $0.2 \%$ aq. colchicine and fixed in acetic-alcohol $(1: 3)$. Before squashing them in $1 \%$ aceto-orcein, root tips were hydrolysed in a mixture of 1 part $\mathrm{N} \mathrm{HCL}$ and 9 parts $1 \%$ aceto-orcein for $15-20$ minutes at $60^{\circ} \mathrm{C}$. Chromosome measurements were made from camera lucida 
drawings. Homologues were identified on the basis of index number (short arm/ long arm ratio; Emsweller and Jones 1935) and r-index value (long arm/short arm ratio; see Bothmer 1977). For identification of centromeric positions the classification recommended by Levan, Fredga and Sandberg (1965) has been followed. Chromosomes have been classified into various types on the basis of $r$-index value, over all length and details of secondary constriction.

For nucleolar studies excised root tips were directly fixed for $24 \mathrm{hrs}$ in Rattenbury's fixative (Rattenbury 1952), hydrolysed at $60^{\circ} \mathrm{C}$ for $2 \mathrm{hrs}$ and squashed in $1 \%$ acetic-carmine. Size comparisons of nucleolus were made on the basis of nucleolar surface area $\left(=4 \pi r^{2}\right)$ which is known to be a better parameter of nucleolar dimensions (Jordan 1971).

\section{Observations}

F. imperialis Linn.

Karyotype (Fig. 1)

With $2 \mathrm{n}=24, F$. imperialis represents a diploid species with its somatic chromosomes ranging in length from 10.5-19.8 $\mu$. Longest chromosome/shortest chromosome size ratio of the complement equals 1.88 . The somatic chromosomes can be classified into five types shown below (Fig. 2, Table 1).

Table 1. Karyotype of F. imperialis

\begin{tabular}{ccccccc}
\hline $\begin{array}{c}\text { Chromosome } \\
\text { type }\end{array}$ & $\begin{array}{c}\text { Position in } \\
\text { the } \\
\text { idiogram }\end{array}$ & $\begin{array}{c}\text { Average } \\
\text { length in } \\
\mu\end{array}$ & $\begin{array}{c}\text { r-Index } \\
\text { value }\end{array}$ & $\begin{array}{c}\text { Index } \\
\text { no. }\end{array}$ & $\begin{array}{c}\text { Position } \\
\text { of } \\
\text { centromere }\end{array}$ & $\begin{array}{c}\text { Details } \\
\text { of } \\
\text { NOR }\end{array}$ \\
\hline A & 1 & 19.2 & 1.3 & 0.72 & $\mathrm{~m}$ & - \\
\hline B & 2 & 18.1 & 1.6 & 0.59 & $\mathrm{~m}$ & - \\
& 3 & 15.8 & 12.1 & 0.08 & $\mathrm{t}$ & - \\
& 4 & 15.1 & 11.9 & 0.08 & $\mathrm{t}$ & - \\
& 5 & 14.3 & 13.3 & 0.07 & $\mathrm{t}$ & - \\
& 6 & 13.2 & 7.9 & 0.12 & $\mathrm{t}$ & - \\
\hline C & 7 & 12.8 & 7.0 & 0.14 & $\mathrm{t}$ & - \\
\hline D & 8 & 12.2 & 7.4 & 0.13 & $\mathrm{t}$ & - \\
& 9 & 11.9 & 5.9 & 0.18 & $\mathrm{st}$ & *NOR in \\
& 10 & 11.5 & 6.5 & 0.15 & $\mathrm{st}$ & the long arm \\
\hline E & 11 & 11.1 & 8.7 & 0.11 & $\mathrm{t}$ & - \\
\hline T.C.L. & 12 & 10.7 & 15.5 & 0.06 & $\mathrm{t}$ & *NOR in \\
\hline * & - & 331.8 & - & - & - & the long arm \\
\hline
\end{tabular}

* NOR distal to centromere.

Nucleolus (Fig. 3)

For nucleolar number a total of 1,015 cells were scored from different root tips.

Figs. 1-3. 1, somatic metaphase of $F$. imperialis showing 24 chromosomes. Scale $5 \mu$. 2, karyoidiogram of the cell in Fig. 1. Scale $5 \mu$. 3, root tip cells of $F$. imperialis showing $1-4$ nucleóli. Scale $30 \mu$. 

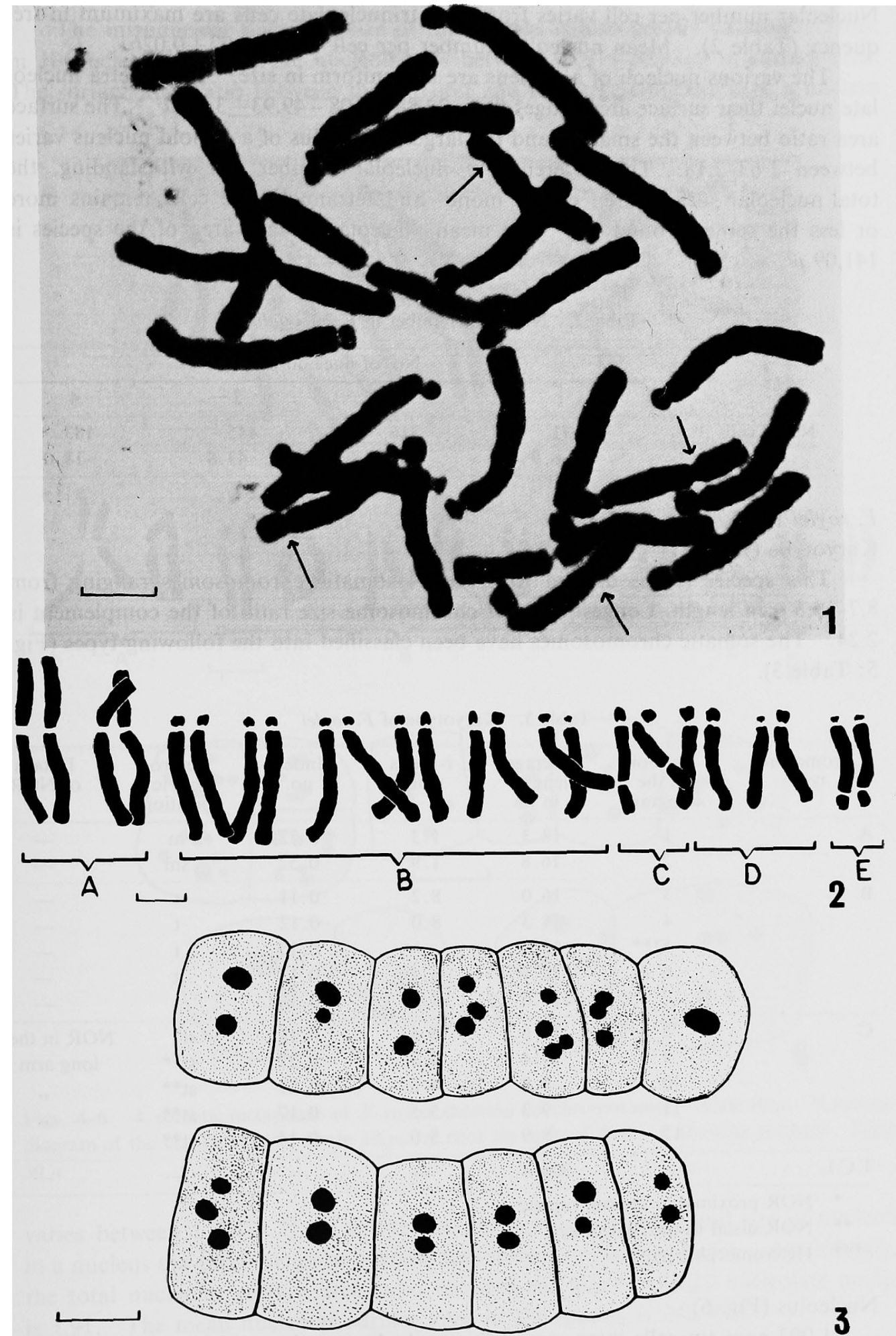
Nucleolar number per cell varies from 1-4, trinucleolate cells are maximum in frequency (Table 2). Mean nucleolar number per cell works $2.72 \pm 0.026$.

The various nucleoli of a nucleus are not uniform in size. In the tetra nucleolate nuclei their surface area ranges from $22.88 \pm 2.08-49.93 \pm 3.69 \mu^{2}$. The surface area ratio between the smallest and the largest nucleolus of a diploid nucleus varies between 1.63-2.18. The difference in nucleolar number not withstanding, the total nucleolar surface area of the mono- and tetranucleolate cells remains more or less the same, around 1.2. The mean nucleolar surface area of the species is $141.09 \mu^{2}$.

Table 2. Nucleolar number in $F$. imperialis

\begin{tabular}{ccccc}
\hline & \multicolumn{4}{c}{ No. of nucleoli per cell } \\
\cline { 2 - 5 } & 1 & 2 & 3 & 4 \\
\hline No. of cells & 71 & 316 & 445 & 183 \\
$\%$ & 6.9 & 31.1 & 43.8 & 18.0 \\
\hline
\end{tabular}

F. roylei Hook.

Karyotype (Fig. 4)

This species too is diploid with the 24 somatic chromosomes ranging from $8.7-19.5 \mu$ in length. Longest/shortest chromosome size ratio of the complement is 2.24. The somatic chromosomes have been classified into the following types (Fig. 5; Table 3).

Table 3. Karyotype of F. roylei

\begin{tabular}{|c|c|c|c|c|c|c|}
\hline $\begin{array}{c}\text { Chromosome } \\
\text { type }\end{array}$ & $\begin{array}{l}\text { Position } \\
\text { in the } \\
\text { idiogram }\end{array}$ & $\begin{array}{l}\text { Average } \\
\text { length } \\
\text { in } \mu\end{array}$ & $\begin{array}{c}\text { r-Index } \\
\text { value }\end{array}$ & $\begin{array}{c}\text { Index } \\
\text { no. }\end{array}$ & $\begin{array}{c}\text { Centro- } \\
\text { meric } \\
\text { position }\end{array}$ & $\begin{array}{l}\text { Details } \\
\text { of NOR }\end{array}$ \\
\hline \multirow[t]{2}{*}{ A } & 1 & 18.3 & 1.3 & 0.72 & $\mathrm{~m}$ & - \\
\hline & 2 & 16.8 & 1.9 & 0.52 & $\mathrm{sm}$ & - \\
\hline \multirow[t]{5}{*}{$B$} & 3 & 16.0 & 8.2 & 0.11 & $t$ & - \\
\hline & 4 & 14.3 & 8.0 & 0.12 & $\mathrm{t}$ & - \\
\hline & $5^{* * *}$ & 13.0 & - & 0.15 & $t$ & - \\
\hline & 6 & 12.7 & 8.3 & 0.12 & $t$ & - \\
\hline & 7 & 11.6 & 8.2 & 0.13 & $t$ & - \\
\hline \multirow[t]{5}{*}{$\mathrm{C}$} & 8 & 11.6 & 5.4 & 0.18 & $\mathrm{st}^{*}$ & NOR in the \\
\hline & 9 & 11.4 & 4.8 & 0.22 & st** & long arm \\
\hline & 10 & 9.8 & 4.6 & 0.21 & $\mathrm{st}^{* *}$ & , \\
\hline & 11 & 9.3 & 5.5 & 0.17 & $\mathrm{st}^{* *}$ & " \\
\hline & 12 & 8.9 & 5.0 & 0.14 & $\mathrm{st}^{* *}$ & ", \\
\hline T.C.L & - & 306.4 & - & - & - & - \\
\hline * NOR p & al to the & tromere & & & & \\
\hline ** NOR di & to the cen & nere & & & & \\
\hline *** Heterom & ohic pair & & & & & \\
\hline
\end{tabular}

Nucleolus (Fig. 6)

1,097 root tip cells were scored for nucleolar number which varies from 1-10 per nucleus. Cells with 5-6 nucleoli per nucleus are, however, maximum in fre- 
quency (Table 4). The mean nucleolar number of the species is $5.6 \pm 0.042$.

The intranuclear nucleolar size of this species is also greatly variable. Thus, in 10 nucleolate nuclei, the nucleoli vary between $11.97-56.93 \mu^{2}$ in surface area. The surface area ratio between the smallest and the largest nucleolus of a nucleus

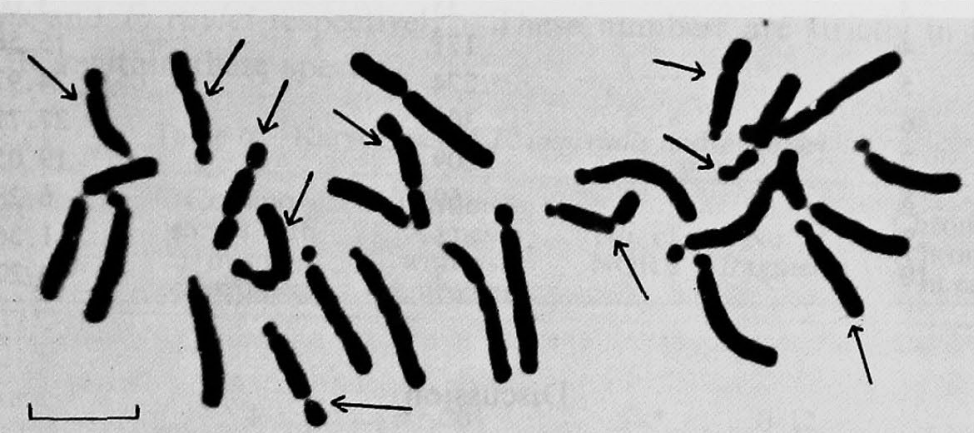

4
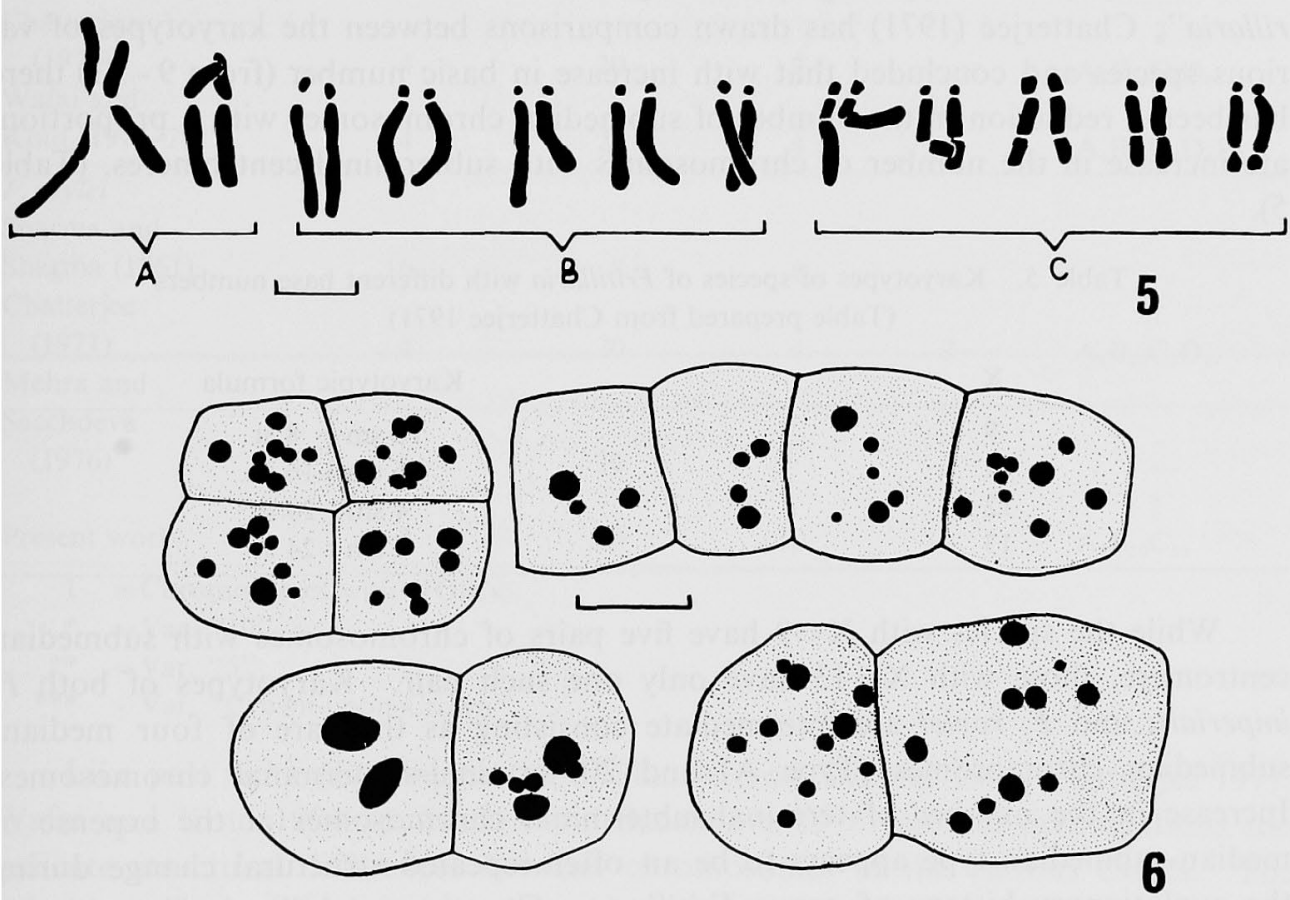

Figs. 4-6. 4, somatic metaphase of F. roylei showing 24 chromosomes. Scale $10 \mu$. 5, karyoidiogram of the cell in Fig. 4. Scale $10 \mu$. 6, root tip cells of F. roylei showing nucleoli. Scale $30 \mu$

varies between $1.76-4.75$. Despite the difference in number and size of nucleoli in a nucleus the total nucleolar surface area remains almost uniform. Accordingly, the total nucleolar surface area ratio between the mono- and 10 nucleolate nuclei is 1.91. The mean nucleolar surface area of the species is $242.40 \mu^{2}$. 
Table 4. Nucleolar number in $F$. roylei

\begin{tabular}{ccc}
\hline $\begin{array}{c}\text { No. of nucleoli } \\
\text { per cell }\end{array}$ & No. of cells & $\%$ Frequency \\
\hline 1 & 2 & 0.18 \\
2 & 17 & 1.54 \\
3 & 33 & 3.00 \\
4 & 171 & 15.58 \\
5 & 274 & 24.97 \\
6 & 304 & 27.71 \\
7 & 209 & 19.05 \\
8 & 69 & 6.28 \\
9 & 15 & 1.36 \\
10 & 3 & 0.27 \\
\hline
\end{tabular}

\section{Discussion}

In his paper on "Cytological investigation on some Himalayan species of Fririllaria"; Chatterjee (1971) has drawn comparisons between the karyotypes of various species and concluded that with increase in basic number (from 9-13) there has been a reduction in the number of submedian chromosomes with a proportionate increase in the number of chromosomes with subterminal centromeres. (Table $5)$.

Table 5. Karyotypes of species of Fritillaria with different base numbers

(Table prepared from Chatterjee 1971)

\begin{tabular}{rc}
\hline $\mathrm{X}$ & Karyotypic formula \\
\hline 9 & $10 \mathrm{sm}+8 \mathrm{st}$ \\
11 & $6 \mathrm{sm}+16 \mathrm{st}$ \\
12 & $4 \mathrm{sm}+20 \mathrm{st}$ \\
13 & $2 \mathrm{sm}+24 \mathrm{st}$ \\
\hline
\end{tabular}

While the species with $X=9$ have five pairs of chromosomes with submedian centromere, those with $\mathrm{X}=13$ have only one such pair. Karyotypes of both $F$. imperialis and $F$. roylei are intermediate consisting as they are of four mediansubmedian chromosomes (Type A) and 20 terminal-subterminal chromosomes. Increase in the number of terminal-subterminal chromosomes at the expense of median-submedian type appears to be an often-repeated structural change during the evolutionary history of genus Fritillaria. Genetic variability in the genus is fostered further by chromosome polymorphism at the interspecific, varietal and even clonal levels. It is, therefore, justified that observations made on karyology do not always agree particularly in respect of position of centromere and number of NOR's (Table 6).

That this intraspecific disparity in the karyotype represents true difference at the varietal or clonal levels is quite probable in view of Dyer's (1963) demonstration of variability in $\mathrm{H}$-band patterns.

Variability with respect to nucleolar chromosomes in both the W. Himalayan species is of particular significance. In order to confirm the number of nucleolar 
chromosomes in $F$. imperialis and $F$. roylei help was drawn from nucleolar studies in root tip cells. These studies revealed direct correlation between nucleolar number per nucleus and the number of NOR's within the chromosome complement. Similar correlation had also been established in $F$. cirrhosa by Chatterjee (1971). Nucleolar studies revealed the presence of a maximum of four and ten nucleoli per nucleus in $F$. imperialis and $F$. roylei respectively. These numbers are strictly in line with 4 and 10 NOR's within these species.

Table 6. Karyotypes of $F$. imperialis and $F$. roylei

\begin{tabular}{|c|c|c|c|c|c|}
\hline $\begin{array}{l}\text { Species } \\
\text { and } \\
\text { authority }\end{array}$ & $\begin{array}{l}\text { Chromo- } \\
\text { somes with } \\
\mathrm{m} / \mathrm{sm} \\
\text { centromere }\end{array}$ & $\begin{array}{c}\text { Chromo- } \\
\text { somes } \\
\text { with } t / s t \\
\text { centromere }\end{array}$ & $\begin{array}{l}\text { No. of } \\
\text { NOR's }\end{array}$ & $\begin{array}{l}\text { No. of } \\
\text { fragments }\end{array}$ & $\begin{array}{l}\text { Chromosome type } \\
\text { /chromosome no. } \\
\text { in each type. }\end{array}$ \\
\hline \multicolumn{6}{|l|}{ F. imperialis } \\
\hline \multicolumn{6}{|l|}{ Darlington } \\
\hline$(1930)$ & 4 & 20 & $\begin{array}{l}-{ }^{*} \\
2^{* *} \\
4^{* * *}\end{array}$ & $0-12$ & - \\
\hline Chatterjee & & & & & 1 \\
\hline (1971) & 4 & 20 & 2 & - & $\mathrm{A}_{4} \mathrm{~B}_{12} \mathrm{C}_{2} \mathrm{D}_{3}$ \\
\hline Wafai and & & & & & 11 \\
\hline Koul (1974-75) & 4 & 20 & 4 & - & $\mathrm{A}_{4} \mathrm{~B}_{12} \mathrm{C}_{2} \mathrm{D}_{4} \mathrm{E}_{2}$ \\
\hline \multicolumn{6}{|l|}{ F. roylei } \\
\hline \multicolumn{6}{|l|}{ Sharma and } \\
\hline Sharma (1961) & 16 & 8 & 8 & - & - \\
\hline Chatterjee & & & & & 1 \\
\hline (1971) & 4 & 20 & 4 & 2 & $\mathrm{~A}_{4} \mathrm{~B}_{12} \mathrm{C}_{4} \mathrm{D}_{4}$ \\
\hline \multicolumn{6}{|l|}{ Mehra and } \\
\hline \multicolumn{6}{|l|}{ Sacchdeva } \\
\hline (1976) & 4 & 20 & 2 & - & - \\
\hline Present work & 4 & 20 & 10 & - & $\begin{array}{c}1 \\
\mathrm{~A}_{4} \mathrm{~B}_{10} \mathrm{C}_{10}\end{array}$ \\
\hline
\end{tabular}

1 =Chromosomes with NOR's

* =Var. " 10 "

** =Var. " 5 "

*** $=$ Var. "Crown-upon-Crown".

Like past work (Darlington 1930, Sharma and Sharma 1961, Chatterjee 1971, Wafai and Koul 1974-75, Mehra and Sacchdeva 1976) present investigations too indicate structural differences between chromosomes of the various clones. The existence of so many structural variants at intraspecific level in both species is rendered possible by vegetative propagation.

\section{Summary}

Morphology of the chromosome complements of the two $\mathrm{N}$ W Himalayan species is at variance with those from other places particularly in respect of centromeric position and the size and number of nucleolar organising regions. Whereas past work on $F$. roylei put the number of NOR's at two and eight per diploid set, present work has revealed occurrence of ten such regions. Again in F. imperialis 
present observations indicate the presence of four NOR's against two suggested by earliar workers. Support for the authenticity of present counts has been drawn from the number of nucleoli organized per nucleus. Structural variability in chromosomes particularly the ones bearing secondary constriction, appears to be the major source of evolution within the genus.

\section{Acknowledgements}

The authors feel grateful to Prof. Y. R. Malhotra, Head of the Department of Biosciences, University of Jammu, for providing necessary facilities and encouragement.

\section{Literature cited}

Bothmer, R, von. 1977. Cytological studies in Allium I. Chromosome numbers and morphology in sect. Allium from Greece. Bot. Notiser 123: 519-551.

Chatterjee, A. 1971. Cytological investigation on a few Himalayan species of Fritillaria. Jour. Cytol. Genet. 6: 117-122.

Darlington, C. D. 1930. Chromosome studies in Fritillaria III. Chiasma formation and chromosome pairing in $F$. imperialis. Cytologia 2: 37-59.

Dyer, A. F. 1963. Allocyclic segments of chromosomes and the structural heterozygosity that they reveal. Chromosoma (Berl.) 13: 545-576.

Emsweller, S. L. and Jones, H. A. 1935. Meiosis in Allium fistulosum, A. cepa and their hybrid. Hillgardia 9: 277-288

Fedorov, A. A. 1969. Chromosome Numbers of Flowering Plants (Ed.). Acad. Sci. U.S.S.R. Leningrad.

Frankel, O. H. 1937. Nucleolar cycle in some species of Fritillaria. Cytologia 8: 37-47.

Jordan, E. G. 1971. The Nucleolus. Oxford Biology Reader's Ed. J. J. Head and O. E. Lowenstein.

Levan, A., Fredga, K. and Sandberg, A. A. 1965. Nomenclature for centromeric position on chromosomes. Hereditas 52: 201-220

Mehra, P. N. and Sacchdeva, S. K. 1976. Cytological observations on some West Himalayan monocots II. Cytologia 41: 5-22.

Rattenbury, J. A. 1952. Specific staining for nucleolar substance with acetocarmine. Stain Technology 27: 113-120.

Sharma, A. K. and Sharma, A. 1961. An investigation of the cytology of some Liliaceae. Genet. Iber. 13: 25-42.

Wafai, B. A. and Koul, A. K. 1974-75, Studies on karyotype of Fritillaria imperialis L. Journ. Cytol. Genet. 9 and 10: 50-52. 